\title{
SUMARNI INVENTAR FONDA NARODNI ODBOR GRADSKE OPĆINE PAZIN 1952. - 1955.
}

\author{
Hendi HRELJA \\ Državni arhiv u Pazinu \\ Pazin, Vladimira Nazora 3 \\ hendi.hrelja@dapa.hr
}

\author{
UDK 352.09(497.571Pazin)
}

(083.22)“1947/1952“"

Stručni rad

Gradivo je nastalo djelovanjem stvaratelja Narodnoga odbora gradske općine Pazin u razdoblju od 1952. do 1955. godine, a pohranjeno je u Državnom arhivu u Pazinu u sklopu fonda HR-DAPA-132, Narodni odbor gradske općine Pazin (1952-1955). U Arhiv je dopremljeno u rasutu stanju, kao dio gradiva cjelokupne pazinske poslijeratne općinske i mjesne uprave te je kasnije izdvojeno u samostalan fond.

Arhivistička je obrada obavljena tijekom 2016. godine. Gradivo je sređeno i popisano te su izdvojene manje količine gradiva povezanih stvaratelja i dio registraturnoga gradiva predloženog za izlučivanje. Sumarni je inventar izrađen u rujnu 2016. godine, a u njemu je Fond opisan višerazinskim sustavom arhivističkoga opisivanja koji daje iscrpan pregled gradiva i povijesti djelovanja stvaratelja.

Ključne riječi: narodni odbor, gradska općina, Pazin, arhivski fond, sumarni inventar

Keywords: People's Committee, municipality, Pazin, arcival fonds, summary inventory

Parole chiave: comitato popolare, comune-città, Pisino, fondo archivistico, inventario sommario

\section{ARHIVISTIČKI OPIS FONDA \\ HR-DAPA-132 NARODNI ODBOR GRADSKE OPĆINE PAZIN}

\author{
IDENTIFIKACIJA
}

\section{Identifikacijska oznaka / signatura}

HR-DAPA-132 


\section{Naslov}

Narodni odbor gradske općine Pazin

\section{Vrijeme nastanka gradiva}

1952-1955

\section{Razina opisa}

Fond

\section{Količina i nosač jedinice opisa}

8 kutija, $0,8 \mathrm{~d} / \mathrm{m}$

\section{KONTEKST}

\section{UPRAVNA POVIJEST STVARATELJA}

\section{Naziv stvaratelja}

Narodni odbor gradske općine Pazin

\section{Vrijeme djelovanja}

1952. -1955.

\section{Povijest}

Narodni odbor gradske općine Pazin djeluje od travnja $1952 .{ }^{1}$ do 31 . kolovoza $1955 .{ }^{2}$ kad se nakon administrativnoga preustroja ukida, a područje njegove nadležnosti prelazi pod novoosnovani Narodni odbor Općine Pazin.

\section{Sjedište}

Pazin

\section{Mjesna nadležnost}

Nadležnost Narodnoga odbora gradske općine Pazin obuhvaćala je mjesta: Bašići, Batlug, Beram, Brajkovići, Butoniga, Čerišnjevica, Dajčići, Dolinci, Frankovići, Gljuščići, Gračišće, Grdoselo, Grubiši, Gržani, Heki, Jašići, Jukini, Kašćerga, Katun Trviški, Križi-

Zakon o podjeli NR Hrvatske na kotare, gradove i općine (NN 16/1952).

2 Zakon o provođenju novog uređenja općina i kotara (NN 33/55); Zakon o području kotara i općina u NR Hrvatskoj (NN 36/55). 
šće Trviško, Kršikla, Lindar, Lindarski Katun, Lukači, Mala Traba, Meletić-breg, Munci, Pazin, Pulići, Pužari, Ruhci, Slavčići, Stari Pazin, Sv. Petar u Šumi, Šajini, Šestani, Šimunčići, Škopljak, Trviž, Turčinovići, Vela Traba, Zabrežani, Zamask Pazinski, Zarečje, Zgrablići i Zovići.

\section{Pravni status}

Tijelo državne uprave, jedinica lokalne razine.

\section{Djelatnost i funkcije}

Narodni odbor grada odnosno gradske općine usmjeravao je i osiguravao privredni, socijalni i kulturni razvitak gradske općine, učvršćivao i razvijao socijalističke odnose i pravni poredak te obavljao druge zakonom određene zadatke. Obavljao je sve poslove od neposrednoga interesa za privredni, komunalni, socijalni i kulturni razvitak gradske općine ako za njih nije zakonom bila određena nadležnost viših državnih organa. Neposredno je izvršavao zakone i druge propise viših državnih organa te obavljao poslove izvršne djelatnosti u odnosu na građane, privredne i društvene organizacije i ustanove kad mu je to zakonom ili drugim propisima stavljeno u nadležnost.

U poslovima od neposrednoga interesa za privredni, komunalni, kulturni i socijalni razvitak grada odnosno gradske općine, koji nisu uređeni zakonom, Narodni odbor grada imao je pravo donositi samostalne propise i druge akte te za povredu svojih propisa svojim odlukama propisivati administrativne kazne određene zakonom. Narodni odbor grada imao je pravo i dužnost na svom području nadzirati privredne i druge organizacije, ustanove i građane, u smislu njihova ispunjavanja odredaba zakona i drugih propisa te voditi upravni i administrativno-kazneni postupak u prvom stupnju ako to zakonom ili drugim propisima nije stavljeno u nadležnost drugih državnih organa. Imao je također pravo upravljanja svim zemljištima i zgradama na svom području koje su općenarodna imovina ako to pravo nije pripadalo drugim državnim organima, privrednim organizacijama, ustanovama ili zajednicama (selima i dr.). Sredstvima iz proračuna imao je pravo osnivanja privrednih poduzeća, komunalnih, kulturnih, prosvjetnih, zdravstvenih i socijalnih ustanova. Zakonom i propisima osnovanim na zakonu imao je određena prava i dužnosti poduzimanja privredno-upravnih i nadzornih mjera prema svim privrednim organizacijama i ustanovama u gradu. Mogao je i izdavati naloge Narodnoj miliciji za osiguranje administrativnoga provođenja određenih akata iz svoje nadležnosti te je bio dužan pružati pravnu pomoć svim drugim državnim organima u obavljanju poslova iz svoje nadležnosti.

Narodni odbor grada obavljao je sve poslove u svojoj nadležnosti na posebnim ili zajedničkim sjednicama svojih vijeća, a upravne poslove preko svojih savjeta.

Gradsko vijeće i Vijeće proizvođača ravnopravno su sudjelovali u donošenju Statuta Narodnoga odbora, generalnog i regulacijskog plana, odluke o društvenom planu, proračunu i završnom računu, rješenja o osnivanju, ukidanju i spajanju ustanova i poduzeća, propisa o privredno-upravnim mjerama, odluka o prirezu i drugim javnim dadžbinama, zaključaka o sklapanju i odobravanju zajmova, odluka o pitanjima radnih odnosa i socijal- 
nog osiguranja te drugih odluka koje su posebnim zakonom ili drugim propisima stavljene u djelokrug Gradskoga vijeća ili Vijeća proizvođača.

Izbori i razrješenja koji su zakonom ili drugim propisima stavljeni u nadležnost Narodnoga odbora grada obavljali su se na zajedničkoj sjednici obaju vijeća, a odnosili su se na izbor i razrješenje predsjednika i potpredsjednika Narodnoga odbora, predsjednika i članova savjeta i zajedničkih komisija, tajnika Narodnoga odbora, načelnika odjela i drugih službenika za koje to odredi zakon ili statut, predsjednika, sudaca i sudaca porotnika kotarskoga i okružnog suda, sudca za prekršaje i njegova zamjenika, članova i tajnika disciplinskoga suda za službenike te direktora poduzeća i rukovodilaca ustanova.

\section{Izvori ovlasti / Zakoni}

- Zakon o podjeli Narodne Republike Hrvatske na kotare, gradove i općine (NN 16/52)

- Zakon o narodnim odborima kotara (NN 34/52)

- Zakon o narodnim odborima općina (NN 35/52)

- Zakon o narodnim odborima gradova i gradskih općina (NN 36/52)

- Opći zakon o uređenju općina i kotara (Sl. list FNRJ 26/55)

- Zakon o provođenju novog uređenja općina i kotara (NN 33/55)

- Zakon o području kotara i općina u Narodnoj Republici Hrvatskoj (NN 36/55)

- Zakon o nadležnosti narodnih odbora općina i kotara (NN 38/55).

\section{Unutarnji ustroj}

Narodni odbor gradske općine sastojao se od trideset do pedeset odbornika. Brojni se sastav odbornika utvrđivao s obzirom na veličinu grada odnosno gradske općine, broj stanovništva, kao i broj privredne, socijalne, kulturne, društvene i komunalne osobine grada, odnosno gradske općine.

Tijekom svoga saziva, odnosno razdoblja za koja je bio izabran, Narodni odbor grada odnosno gradske općine stalno je održavao sjednice te radio na sjednicama ili preko savjeta ili komisija. Posebne ili zajedničke sjednice Vijeća Narodnoga odbora gradske općine sazivao je predsjednik Narodnoga odbora. Vijeća narodnoga odbora gradske općine pravovaljano su rješavala predmete ako je na sjednicama bila prisutna većina njihovih članova, a zaključke su donosila većinom glasova prisutnih odbornika ako za pojedine slučajeve zakonom ili statutom nije bila određena kvalificirana većina.

Za proučavanje pojedinih pitanja i pripremanje zaključaka, kao i za anketiranje Vijeća, Narodni odbor gradske općine birao je iz svoje sredine stalne i povremene komisije. Stalne su se komisije birale na prvom sastanku za cijelo izborno razdoblje, a povremene komisije birale su se prema potrebi i radile su dok ne bi završile posao koji im je bio povjeren, odnosno do svoga razrješenja.

Gradsko vijeće imalo je sljedeće stalne komisije:

1. Mandatno-imunitetsku komisiju 
2. Komisiju za društveni plan i financije

3. Komisiju za propise i organizacijska pitanja

4. Komisiju za molbe i žalbe.

Vijeće proizvođača imalo je sljedeće stalne komisije:

1. Mandatno-imunitetsku komisiju

2. Komisiju za društveni plan i financije.

Zajedničke stalne komisije obaju vijeća Narodnoga odbora gradske općine bile su:

1. Komisija za izbor i imenovanja

2. Računska komisija.

Komisije su se bavile proučavanjem prijedloga koje su pojedinim vijećima Narodnoga odbora gradske općine podnosili predsjednik Narodnoga odbora, savjeti, odbornici, zborovi birača, društvene organizacije i građani i davale o njima svoje mišljenje.

Komisija za izbore i imenovanja proučavala je prijedloge za izbore i imenovanja, kao i razloge za razrješavanje svih organa i službenika koje je Narodni odbor gradske općine birao na zajedničkoj sjednici obaju vijeća.

Računska je komisija kontrolirala izvršenja proračuna i društvenoga plana Narodnoga odbora, zajedno s drugim dužnostima koje joj je odredio Narodni odbor.

U sastavu Narodnoga odbora gradske općine osnivali su se pojedini savjeti kojima se povjeravalo provođenje zakona, propisa Narodnoga odbora i viših državnih organa, kao i obavljanje upravnih poslova. Savjet je bio kolegijalno tijelo sastavljeno od predsjednika i četiriju do osam članova.

Narodni odbor gradske općine mogao je imati sljedeće savjete: Savjet za privredu, Savjet za komunalne poslove, Savjet za prosvjetu i kulturu, Savjet za narodno zdravlje i socijalnu politiku te Savjet za unutrašnje poslove.

Savjet za privredu bavio se sastavljanjem prijedloga društvenoga plana te poslovima financija, kao i poslovima sljedećih grana državne uprave, odnosno službi kao što su industrija, poljoprivreda, šumarstvo, lovstvo i ribarstvo, zanatstvo, trgovina, ugostiteljstvo i turizam.

Savjet za komunalne poslove bavio se poslovima iz grana državne uprave, odnosno službi kao što su lokalni promet, građevinarstvo, urbanizam, vodoprivreda, stambena pitanja te druge komunalne djelatnosti.

Savjet za prosvjetu i kulturu bavio se poslovima iz grana državne uprave, odnosno službi kao što su predškolski odgoj, školstvo, narodno prosvjećivanje i druge kulturne djelatnosti, tjelesni odgoj naroda i predvojnička obuka.

Savjet za narodno zdravlje i socijalnu politiku obuhvaćao je poslove iz grana državne uprave, odnosno službi kao što su narodno zdravlje, socijalna skrb, socijalno osiguranje, radni odnosi i posredovanje rada. 
Savjet za unutrašnje poslove obavljao je dužnosti iz grana državne uprave, odnosno službi kao što su zaštita pravnog poretka, reda i mira, sigurnosti prometa, građansko stanje, kriminalistička služba, vatrogasna služba i protuavionska zaštita.

Predsjednik je Narodnoga odbora biran iz reda odbornika za čitavo izborno razdoblje, ali ga je Narodni odbor mogao razriješiti dužnosti i prije isteka toga razdoblja. Predsjednik se brinuo o provođenju odluka i drugih akata i mjera Narodnoga odbora i propisa viših državnih organa, usklađivao rad svih organa Narodnoga odbora te je nadzirao rad administracije Narodnoga odbora.

Za vođenje administrativno-kaznenoga postupka i izricanja administrativnih kazni Narodni odbor gradske općine birao je, uz suglasnost republičkoga organa nadležnoga za unutarnje poslove, potreban broj sudaca za prekršaje i njihove zamjenike koji su za svoj rad odgovarali Narodnom odboru.

Za pripremu i odrađivanje poslova iz svoje nadležnosti Narodni odbor gradske općine imao je svoju administraciju. Administracijom i radom službenika Narodnoga odbora upravljao je tajnik Narodnoga odbora, pod nadzorom predsjednika Narodnoga odbora. Administracija se sastojala od Tajništva i potrebnoga broja odjela. Tajništvo je obavljalo zajedničke i druge opće poslove Narodnoga odbora. Odjeli su se osnivali kako bi se odrađivali poslovi iz djelokruga pojedinih savjeta. U narodnim odborima gradskih općina mogli su se umjesto odjela za poslove iz djelokruga pojedinih savjeta osnivati odsjeci odnosno referade u sastavu Tajništva. Tajništvo, odjeli i odsjeci mogli su se dijeliti na manje organizacijske jedinice. Organizacija administracije utvrđivala se statutom Narodnoga odbora, sukladno zakonskim propisima. Radom Tajništva neposredno je upravljao tajnik Narodnoga odbora. Radom odjela neposredno je upravljao načelnik koji je ujedno bio i tajnik savjeta, a radom odsjeka šef odsjeka.

U svrhu rasprave o radu i zadatcima Narodnoga odbora, njegovih organa i ustanova te radi razmatranja i predlaganja mjera za razvitak grada odnosno gradske općine održavali su se zborovi birača. Zborovi birača mogli su raspravljati i davati svoja mišljenja i prijedloge o pitanjima od značaja za život kotara kao cjeline, narodne republike i državne zajednice, kao i o pitanjima koja su iznesena na općenarodnoj raspravi ili za koja bi to zatražili državni organi.

Radi sudjelovanja što većeg broja građana u radu lokalne uprave u gradu odnosno gradskoj općini narodni odbori mogli su za pojedine grane uprave ili za pojedina područja djelatnosti osnovati savjete i komisije građana. O sastavu, djelokrugu i radu ovih savjeta i komisija rješavalo se aktom o njihovu osnivanju.

\section{Opći kontekst}

Prvi poslijeratni zakonski teritorijalni ustroj lokalnih jedinica u Narodnoj Republici Hrvatskoj uveden je Zakonom o administrativno-teritorijalnoj podjeli Narodne Republike Hrvatske iz 1947. godine (NN 60/47), ali njime nije obuhvaćena Istra, kao ni njezini kotarevi i gradovi. To je ostvareno tek 1948. godine Zakonom o izmjenama i dopunama Zakona o administrativno-teritorijalnoj podjeli NRH (NN 42/48). Njime je područje Istre, osim 
Kotara Buje, uklopljeno u pravno-politički sustav Narodne Republike Hrvatske, odnosno Federativne Narodne Republike Jugoslavije, a definirani su i broj i nadležnost kotareva, gradova i mjesnih narodnih odbora. Temeljem Zakona o administrativno-teritorijalnoj podjeli Narodne Republike Hrvatske (NN 29/49) te Zakona o administrativno-teritorijalnoj podjeli Narodne Republike Hrvatske i Uputstva o pripajanju područja ukinutih mjesnih narodnih odbora drugim administrativno-teritorijalnim jedinicama (NN 27/50) Istra je postala dijelom riječke oblasti te su izmijenjeni broj i mjesna nadležnost pojedinih mjesnih narodnih odbora.

Administrativnim preustrojem iz 1952. godine ${ }^{3}$ teritorij Narodne Republike Hrvatske podijeljen je na kotareve, gradove, gradske općine i općine. Mjesni narodni odbori prestaju postojati te se njihova područja nadležnosti i funkcije djelovanja prenose na gradske i općinske narodne odbore. Detaljnija organizacija uprave provedena je donošenjem Zakona o narodnim odborima kotara (NN 34/52), Zakona o narodnim odborima gradova i gradskih općina (NN 36/52) i Zakona o narodnim odborima općina (NN 35/52). Područje Istre bilo je podijeljeno na kotare Buzet, Labin, Pazin, Poreč i Pula. Narodni odbor Kotara Pazin obuhvaćao je Narodne odbore Općina Cerovlje, Lupoglav, Motovun, Pićan, Tinjan i Žminj te Narodni odbor gradske općine Pazin.

Uvođenjem »novog komunalnog sustava« 1955. godine ${ }^{4}$ dolazi do preustroja administrativno-teritorijalnih jedinica, a dotadašnje gradske općine i općine prelaze u novoosnovane općine. Sukladno Zakonu o području općina i kotara u NRH (NN 36/55) rasformirani su dotadašnji narodni odbori kotara Pazina, Poreča, Pule, Labina, Buzeta i Buja, a njihov teritorij prelazi pod nadležnost novoosnovanoga Narodnog odbora kotara Pula koji je obuhvaćao 14 općina: Buje, Buzet, Labin, Motovun, Novigrad, Pazin, Potpićan, Poreč, Pula, Rovinj, Umag, Višnjan, Vodnjan i Žminj.

\section{VEZE}

Neposredni su prednici Narodnoga odbora gradske općine Pazin bili Mjesni narodni odbori Pazin, Gračišće, Kašćerga, Katun Trviški i Sveti Petar u Šumi, koji su djelovali od srpnja 1947. do travnja 1952. kad su ukinuti, a područje je njihove nadležnosti prešlo pod novoosnovani Narodni odbor gradske općine Pazin.

Sljednik Narodnoga odbora gradske općine Pazin bio je Narodni odbor općine Pazin koji je osnovan 1955. godine ukinućem stvaratelja.

Narodnom odboru gradske općine Pazin neposredno je bio nadređen Kotarski narodni odbor Pazin, odnosno od 1952. godine Narodni odbor kotara Pazin koji je djelovao od 1945.

Zakon o podjeli Narodne Republike Hrvatske na kotare, gradove i općine (NN 16/52).

$4 \quad$ Zakon o uređenju općina i kotara (S1. list FNRJ 26/55); Zakon o provođenju novog uređenja općina $i$ kotara (NN 33/55). 
do 1955. godine kad je ukinut, a područje je njegove nadležnosti prešlo pod Narodni odbor kotara Pule čija se nadležnost protezala na cijelo područje današnje Istarske županije.

\section{Povijest Fonda}

Prestankom djelovanja stvaratelja gradivo je ostalo u posjedu sljednika. U Arhiv je preuzeto od Skupštine Općine Pazin u sklopu cjeline gradiva poslijeratne pazinske općinske i mjesne uprave 1972. i 1973. godine. Gradivo je preuzeto u rasutu stanju, zajedno s gradivom ostalih povezanih stvaratelja s kojim se čuvalo u spremištu predavatelja. Okvirno je sređeno i evidentirano te izdvojeno od gradiva povezanih stvaratelja. Sumarni inventar, koji sadrži četiri stranice rukopisa, izradila je 1974. godine Zdenka Filiplić, a vodič kroz arhivski fond i matični list izradila je Ljiljana Radaljac.

Arhivističkoj se obradi pristupilo tijekom 2016. godine. Tijekom procesa izdvojene su manje količine gradiva povezanih stvaratelja te je provedeno odabiranje i izlučivanje. Sumarni je inventar izrađen u rujnu 2016.

\section{Način preuzimanja ili predaje}

Gradivo je u Državni arhiv u Pazinu (tada Historijski arhiv u Pazinu) preuzeto od Skupštine Općine Pazin 1972. i 1973. godine temeljem Zapisnika br. 293/1-1973 od 25. 8. 1972. i Ugovora br. 01-538/73 od 29. 10. 1973. godine. Evidentirano je u Knjizi akvizicije pod brojem 85 (ponovljeni upis: 147-168) i 108/109 (ponovljeni upis: 173). Gradivo NOGO-a Pazin evidentirano je u Knjizi akvizicije (1960. - 2004.) pod br. 151.

\section{SADRŽAJ I USTROJ FONDA}

\section{Sadržaj}

Gradivo je nastalo radom stvaratelja Narodnoga odbora gradske općine Pazin u razdoblju od 1952. do 1955. godine. Od registraturnih pomagala tu su urudžbeni zapisnici »općih« i »povjerljivih« spisa koji prate spomenute spise sukladno rastućem broju zapisnika. Gradivo također sadrži zapisnike sjednica zajedno s knjigama zapisnika i odluka NOGO-a Pazin te razna predmetna kazala. Sadržani su i opći upravni spisi, od kojih su najbrojniji razni statistički izvještaji. Iz domene unutarnjih poslova sadržane su razne odluke u svezi s održavanjem javnoga reda i mira u mjestu, spisi iz područja matičarstva te razni kazneni i prekršajni postupci. Najveći se dio gradiva odnosi na spise privredne tematike, od kojih velik dio obuhvaća komunalne, odnosno građevinske i projektantske poslove, tj. razne projekte, tehničke preglede, građevinske dozvole te stambene poslove, odnosno procjene i rješenja o dodjeli stanova i dr. Od privrednih spisa tu su još i spisi obrtničke tematike te poljoprivreda, šumarstvo, trgovina i opskrba, ugostiteljstvo i turizam, zadrugarstvo, promet i dr. Veći dio gradiva obuhvaća i spise financijske tematike, od kojih su najbrojniji oni imovinsko-pravne problematike, a sadržava i razne završne račune ustanova i privrednih 
organizacija, proračunske planove i izvješća, dotacije, kredite, spise ustanova sa samostalnim financiranjem, platne liste, spise o porezima i prihodima te geodetsko-katastarske spise. Manji se dio spisa odnosi na rad i radne odnose, prosvjetu, pravosuđe, socijalnu i zdravstvenu zaštitu te narodnu obranu.

\section{Odabiranje i izlučivanje}

Budući da nije sačuvana nikakva dokumentacija koja bi kazivala o prethodno provedenom odabiranju i izlučivanju, tijekom arhivističke obrade provedeno je odabiranje i izlučivanje ${ }^{5}$ manjega dijela registraturnog gradiva te je izrađen prijedlog za izlučivanje.

\section{Dopune}

Moguće su dopune naknadno preuzetim gradivom iz pismohrane Grada Pazina koje još nije dopremljeno u Arhiv ili gradivom umetnutim među fondove upravno-povijesno povezanih stvaratelja.

\section{Plan sređivanja}

Budući da najveći dio gradiva pripada cjelini tzv. »općih spisa« koji se prvobitno javljaju prema rastućem broju glavnih i povjerljivih urudžbenih zapisnika, bilo je potrebno te spise uklopiti u posebne serije, sukladno funkcionalno-sadržajnom načelu sređivanja čuvajući prvobitni red gradiva. Njima je pridodan i ostali dio gradiva, prethodno već raspoređen na određene sadržajne cjeline. Serije su stoga formirane prema grupama poslova iz djelokruga organa uprave koje obuhvaćaju sadržajno srodno gradivo. Radi preciznijega pregleda grupa poslova negdje su formirane i serije i podserije. Na najnižim razinama strukture Fonda gradivo je posloženo kronološki, odnosno sukladno prethodno brojčanom i kronološkom redoslijedu spisa ako se odnosi na tzv. »opće spise«.

\section{Struktura Fonda}

1. REGISTRATURNA POMAGALA

2. OPĆI POSLOVI

3. RAD I RADNI ODNOSI

4. UNUTRAŠNJI POSLOVI

5. PRIVREDA

6. FINANCIJE

7. ZDRAVSTVO I SOCIJALNA ZAŠTITA

8. PROSVJETA I KULTURA

9. PRAVOSUĐE

10. NARODNA OBRANA

5 Pravilnik o vrednovanju te postupku odabiranja i izlučivanja gradiva (NN 90/02). 


\section{DOSTUPNOST I KORIŠTENJE}

\section{Uvjeti dostupnosti i korištenja}

Fond ima status javnoga arhivskog gradiva koje je dostupno sukladno Zakonu o arhivskom gradivu i arhivima (NN 46/17), Zakonu o zaštiti osobnih podataka (NN 106/12), Zakonu o pravu na pristup informacijama (NN 85/15) te Pravilniku o korištenju arhivskog gradiva (NN 67/99).

\section{Uvjeti objavljivanja ili umnožavanja}

Dostupno gradivo dopušteno je objavljivati i umnažati. Uvjeti umnožavanja digitaliziranoga gradiva i uvjeti objavljivanja utvrđuju se posebnim ugovorom između Državnoga arhiva u Pazinu i korisnika arhivskoga gradiva.

\section{Jezik i pismo}

Jezik: najvećim dijelom hrvatski, u manjem broju spisa talijanski, a nekoliko na slovenskom i srpskom jeziku.

Pismo: latinica. Uglavnom strojopis, manjim dijelom rukopis.

\section{Tvarne značajke i tehnički uvjeti}

Cjelokupno je gradivo zapisano na papiru. Najveći je dio spisa pisan na uredskom papiru i tiskanim obrascima. Gradivo je uglavnom vrlo dobro sačuvano: manji je dio spisa i uveza mehanički oštećen (izgužvani ili djelomice poderani papiri, otkinute korice i uvezi) i kemijski oštećen (žutilo ili i izblijedjeli tekst).

\section{Obavijesna pomagala}

HRELJA, Hendi. HR DAPA 132 Narodni odbor gradske općine Pazin: sumarni inventar. Državni arhiv u Pazinu, 2016.

\section{DOPUNSKI IZVORI}

\section{Postojanje i mjesto čuvanja izvornika}

Izvornici se čuvaju u Državnom arhivu u Pazinu na adresi Istarskoga razvoda 2.

\section{Postojanje i mjesto čuvanja preslika}

Preslici gradiva nisu izrađeni.

\section{Dopunski izvori}

1. HR-DAPA-459 Gradski narodnooslobodilački odbor Pazin 1945-1946. 
2. HR-DAPA-194 Mjesni narodni odbor Pazin 1947-1952.

3. HR-DAPA-163 Mjesni narodni odbor Gračišće 1947-1952.

4. HR-DAPA-171 Mjesni narodni odbor Kašćerga 1947-1952.

5. HR-DAPA-173 Mjesni narodni odbor Katun Trviški 1947-1952.

6. HR-DAPA-211 Mjesni narodni odbor Sveti Petar u Šumi 1947-1952.

7. HR-DAPA-87 Narodni odbor kotara Pazin 1945-1955.

8. HR-DAPA-102 Narodni odbor općine Pazin 1955-1963.

\section{KONTROLA OPISA}

\section{Identifikator ustanove i opisa}

HR DAPA ObP-132/SI-1.2

\section{Pravila ili propisi}

ISAD (G), Opća međunarodna norma za opis arhivskog gradiva, Zagreb, Hrvatski državni arhiv, 2001.

ISAAR (CPF), Međunarodna norma arhivističkog normiranog zapisa za pravne i fizičke osobe te obitelji, Zagreb, Hrvatski državni arhiv, 2006.

\section{Napomena arhivista}

1. Na razini opisa Fonda sadržaj elementa opisa Upravna povijest (ISAD(G) 3.2.2.) zamijenjen je razrađenijim elementima iz ISAAR(CPF), 5.2. Područje opisa.

2. Na razini opisa Fonda elementi područja Kontrole opisa (ISAD $(G)$ ) zamijenjeni su razrađenijim oblikom iz ISAAR(CPF), 5.4. Područje kontrole.

3. Na mjestu upravne povijesti ili biografskih podataka iz $\operatorname{ISAD}(\mathrm{G})$-a iskorišten je element Opći kontekst iz ISAAR(CPF) radi razmatranja širega konteksta djelovanja stvaratelja.

\section{Izvori}

ŽUŽIĆ, Patricija. Teritorijalno-administrativni ustroj na području današnje Istarske županije za razdoblje od 1945. do 1990. godine: prilog za izradu shematizma uprave. Državni arhiv u Pazinu, 2007.

Ostali su izvori navedeni u bilješkama ispod teksta opisa.

\section{Status}

Dovršena i odobrena verzija (09-2016, Hrelja). 


\section{Nadnevak nastanka}

HR DAPA ObP-132/SI-1, rujan 2016.

\section{OPISI I INVENTARNI POPISI NIŽIH RAZINA FONDA}

\section{II/1. REGISTRATURNA POMAGALA}

Signatura
Naslov
Vrijeme nastanka gradiva
Razina opisa
Količina i nosač zapisa
Sadržaj

Plan sređivanja
HR-DAPA-132/1

Registraturna pomagala

1952-1955

Serija

2 kutije, $0,2 \mathrm{~d} / \mathrm{m}$

Gradivo se sastoji od urudžbenih zapisnika (općih i povjerljivih spisa) te predmetnih i drugih kazala.

1.1. Urudžbeni zapisnici

1.2. Kazala

Popis gradiva serije 1

\begin{tabular}{|l|l|l|l|l|}
\hline Signatura & Sadržaj - opis & Godina & $\begin{array}{l}\text { Količina i broj } \\
\text { knjige }\end{array}$ & $\begin{array}{l}\text { Tehnička } \\
\text { jedinica }\end{array}$ \\
\hline 1.1. & Urudžbeni zapisnici & & & Kutija 1 \\
\hline 1.1 .1$. & Povjerljivi urudžbeni zapisnik & $1953-1955$ & 1 knjiga (1) & \\
\hline 1.1.2. & Urudžbeni zapisnici općih spisa & $1952-1954$ & 3 knjige (2 - 4) & \\
\hline 1.1.3. & Urudžbeni zapisnik općih spisa & 1955 & 1 knjiga (5) & Kutija 2 \\
\hline 1.2. & Kazala & & & \multirow{2}{*}{ Kutija 2 } \\
\hline 1.2.1. & Predmetna kazala za 1952. i 1954. godinu & 1952.1954 & 2 knjige (6, 7) & \\
\hline 1.2.2. & Indeks (kazalo) & 1953 & 1 knjiga (11) & \\
\hline
\end{tabular}

\section{II/2. OPĆI POSLOVI}

$\begin{array}{ll}\text { Signatura } & \text { HR-DAPA-132/2 } \\ \text { Naslov } & \text { Opći poslovi } \\ \text { Vrijeme nastanka gradiva } & 1952-1955 \\ \text { Razina opisa } & \text { Serija } \\ \text { Količina i nosač zapisa } & 0,06 \mathrm{~d} / \mathrm{m}\end{array}$


Sadržaj

\section{Plan sređivanja}

Serija sadrži zapisnike sjednica s popratnim materijalom, razne dopise, okružnice, odluke i pravilnike u svezi s općim upravnim poslovima i administrativnom problematikom, spise u svezi s djelovanjem zborova birača te odbornika, raznih vijeća i savjeta, organizacijsko-sistematizacijske poslove, izvještaje o radu, zapisnike s konferencija, problematiku odnosa s inozemstvom, okružnice u svezi s radom Javnog pravobraniteljstva SFRJ, zatim razne statističke izvještaje te izvještaje i podatke u svezi s izborima i biračke popise.

2.1. Zapisnici (sazivi) sjednica i odluke NOGO-a Pazin

2.2. Opći poslovi

2.3. Zborovi birača

2.4. Organizacija vlasti

2.5. Organizacija uprave

2.6. Upravno poslovanje

2.7. Opći upravni poslovi

2.8. Statistika

2.9. Izbori i birački popisi

\section{Popis gradiva serije 2}

\begin{tabular}{|c|c|c|c|}
\hline Signatura & Sadržaj - opis & Godina & $\begin{array}{l}\text { Tehnička } \\
\text { jedinica }\end{array}$ \\
\hline 2.1. & Zapisnici (sazivi) sjednica i odluke NOGO-a Pazin & & Kutija 2-3 \\
\hline 2.1.1. & Knjige zapisnika sjednica NOGO-a Pazin & $1952-1953$ & \multirow[t]{2}{*}{ Kutija 2} \\
\hline 2.1.2. & Knjige odluka NOGO-a Pazin & $1952-1955$ & \\
\hline 2.1.3. & $\begin{array}{l}\text { Zapisnici sjednica NOGO-a Pazin, saziv i dnevni red sjedni- } \\
\text { ca, primjedbe na donesene odluke }\end{array}$ & $1952 / 1955$ & Kutija 3 \\
\hline 2.2. & Opći poslovi & & \multirow[t]{7}{*}{ Kutija 3} \\
\hline 2.2.1. & $\begin{array}{l}\text { Pravilnik o načinu označivanja imena naseljenih mjesta - pro- } \\
\text { vedba, promjena imena privrednih organizacija }\end{array}$ & 1952 & \\
\hline 2.2 .2 . & $\begin{array}{l}\text { Popis sela i naselja s kućnim brojevima na području NOGO-a } \\
\text { Pazin }\end{array}$ & 1953 & \\
\hline 2.2.2. & $\begin{array}{l}\text { Davanje imena mjestima, ulicama, privrednim organizacija- } \\
\text { ma, ustanovama i dr. - okružnice, revizije i zaključci }\end{array}$ & 1954 & \\
\hline 2.2.3. & Upravljanje grobljima - dopis i okružnica & 1954 & \\
\hline 2.2.4. & Formiranje komisije za odlikovanje & 1954 & \\
\hline 2.2.5. & $\begin{array}{l}\text { Odluka o prijenosu nekih poslova iz nadležnosti NOK-a Pazin } \\
\text { u nadležnost NO-a područnih općina }\end{array}$ & 1955 & \\
\hline \multirow[t]{2}{*}{ 2.3. } & Zborovi birača & \multirow[t]{2}{*}{$1952-1954$} & \multirow[t]{2}{*}{ Kutija 3} \\
\hline & Zapisnici, sazivi i zaključci Zbora birača & & \\
\hline \multirow[t]{2}{*}{2.4} & Organizacija vlasti & \multirow[t]{2}{*}{$1952-1955$} & \multirow[t]{2}{*}{ Kutija 3} \\
\hline & $\begin{array}{l}\text { Dopisi u svezi s održavanjem sjednica, formiranjem savjeta, } \\
\text { brojčanim sastavom NO-a, imenovanjem odbornika, razr- } \\
\text { ješenjem dužnosti, postavljanjem članova savjeta, izborom } \\
\text { članova općinskoga vijeća i NO-a, podatci o predsjedniku, } \\
\text { podpredsjedniku i tajniku NO-a, izvod iz zakona o izboru i } \\
\text { broju odbornika }\end{array}$ & & \\
\hline
\end{tabular}




\begin{tabular}{|c|c|c|c|}
\hline \multirow[t]{2}{*}{2.5 . } & Organizacija uprave & \multirow[t]{2}{*}{1953.1955} & \multirow[t]{2}{*}{ Kutija 3} \\
\hline & $\begin{array}{l}\text { Organizacija službi, sistematizacija i raspored radnih mjesta u } \\
\text { administraciji }\end{array}$ & & \\
\hline 2.6 . & Upravno poslovanje & & \multirow[t]{3}{*}{ Kutija 3} \\
\hline 2.6 .1 . & Zapisnik o primopredaji dužnosti & 1952 & \\
\hline 2.6 .2 . & $\begin{array}{l}\text { Dužnosti odbornika, okružnice i upute u svezi s administra- } \\
\text { tivnim i službeničkim poslovima, sjednice stalnih konferenci- } \\
\text { ja gradova i gradskih općina - dnevni red, odluke o stavljanju } \\
\text { izvan snage odluka, izvještaji o radu općinskih i kotarskih } \\
\text { NO-a te NOGO-a Pazin, zapisnik Konferencije o problemima } \\
\text { komuna Istre, problemi čuvanja i primopredaje arhivskoga i } \\
\text { registraturnog materijala, zapisnici savjetovanja predsjednika } \\
\text { i tajnika NO-a }\end{array}$ & $1952-1955$ & \\
\hline \multirow[t]{2}{*}{ 2.7 } & Opći upravni poslovi & \multirow[t]{2}{*}{ 1953-1954 } & \multirow[t]{2}{*}{ Kutija 3} \\
\hline & $\begin{array}{l}\text { Javno pravobraniteljstvo SFRJ - vođenje imovinsko-pravnih } \\
\text { poslova u svezi s inozemnim pitanjima, podatci o arhivama } \\
\text { i dokumentima u Trstu, okružnica Izvršnoga vijeća NR Hr- } \\
\text { vatske o komunikaciji s inozemstvom, podatci i izvješće o } \\
\text { austrijskoj imovini, dostavljanje podataka o imovini u svrhu } \\
\text { reguliranja potraživanja vlade SAD-a, Služba međunarodne } \\
\text { pravne pomoći }\end{array}$ & & \\
\hline \multirow[t]{2}{*}{2.8.} & Statistika & \multirow[t]{2}{*}{$1952-1955$} & \multirow[t]{2}{*}{ Kutija 3} \\
\hline & $\begin{array}{l}\text { Obilježavanje kućnih brojeva, popisi stanovništva - nacrti, } \\
\text { komisije, skice i popisnice; statističke okružnice i upute, ažur- } \\
\text { nost statističkih podataka, statistički podatci, izvještaji i pro- } \\
\text { cjene, mrtvozornička služba - prikupljanje podataka o uzroku } \\
\text { smrti, razne evidencije i dr. }\end{array}$ & & \\
\hline \multirow[t]{2}{*}{2.9.} & Izbori i birački popisi & \multirow[t]{2}{*}{$1952-1954$} & \multirow[t]{2}{*}{ Kutija 3} \\
\hline & $\begin{array}{l}\text { Izbori - rezultati glasovanja, upute u svezi s biračkim popi- } \\
\text { sima, izborne jedinice i broj odbornika, revizije biračkih po- } \\
\text { pisa, podatci o biračkim mjestima, odborima i dr., prijedlozi } \\
\text { i imenovanja biračkih odbora, rješenje za dopunske izbore i } \\
\text { izvještaj o glasovanju }\end{array}$ & & \\
\hline
\end{tabular}

\section{II/3. RAD I RADNI ODNOSI}

Signatura

Naslov

Vrijeme nastanka gradiva

Razina opisa

Količina i nosač zapisa

Sadržaj
HR-DAPA-132/3

Rad i radni odnosi

1952-1955

Serija

$0,01 \mathrm{~d} / \mathrm{m}$

Serija obuhvaća spise koji se odnose na problematiku zapošljavanja, razne uredbe, upute i okružnice u svezi sa zvanjima, plaćama i raznim dodatcima uz plaće, uputama za stručne ispite, okružnicama i rješenjima povezanim s disciplinskim sudovima te problematikom uključivanja učenika u privredu. 


\section{Plan sređivanja}

3.1. Posredovanje rada i briga o nezaposlenima

3.2. Radni odnosi i plaće

3.3. Stručno obrazovanje i stručni ispiti

3.4. Disciplinski sudovi

3.5. Učenici u privredi

\section{Popis gradiva serije 3}

\begin{tabular}{|c|c|c|c|}
\hline Signatura & Sadržaj - opis & Godina & \begin{tabular}{|l} 
Tehnička \\
jedinica
\end{tabular} \\
\hline \multirow[t]{2}{*}{ 3.1. } & Posredovanje rada i briga o nezaposlenima & \multirow[t]{2}{*}{1953} & \multirow{2}{*}{ Kutija 3} \\
\hline & $\begin{array}{l}\text { Zapošljavanje završenih đaka ekonomskih tehnikuma u } \\
\text { narodnim odborima }\end{array}$ & & \\
\hline \multirow[t]{2}{*}{3.2.} & Radni odnosi i plaće & \multirow[t]{2}{*}{$1952-1955$} & \multirow[t]{2}{*}{ Kutija 3} \\
\hline & $\begin{array}{l}\text { Razne okružnice i upute, postavljanje službenika, žalbe pro- } \\
\text { tiv rješenja o prevođenju, Osnovna uredba o zvanjima i pla- } \\
\text { ćama službenika državnih organa - primjena, rješenja i od- } \\
\text { luke o položajnom dodatku i dopunskim plaćama, evidencija } \\
\text { rukovodnog i stručnog kadra u NO-ima, primjena Uredbe } \\
\text { o novčanoj naknadi i Uredbe o dodatcima na djecu, Uredba } \\
\text { o putnim i selidbenim troškovima službenika i radnika - } \\
\text { propisi, dodatak na rad, odluke o dnevnicama i paušalnim } \\
\text { naknadama, zapisnici u predmetu kvalifikacija radnika, } \\
\text { nagrade i odlikovanja službenika, odobrenje povišenja broja } \\
\text { službenika, ovjera prijepisa vojnih knjižica, uredbe i propisi } \\
\text { o zvanjima i plaćama državnih službenika - upute, komisija } \\
\text { za umirovljenje vojnih osoba }\end{array}$ & & \\
\hline \multirow[t]{2}{*}{ 3.3. } & Stručno obrazovanje i stručni ispiti & \multirow[t]{2}{*}{1954} & \multirow[t]{2}{*}{ Kutija 3} \\
\hline & Stručni ispiti - upute & & \\
\hline \multirow[t]{2}{*}{3.4 . } & Disciplinski sudovi & \multirow[t]{2}{*}{$1952-1955$} & \multirow[t]{2}{*}{ Kutija 3} \\
\hline & $\begin{array}{l}\text { Rješenja o prekršaju, disciplinski sudovi - pravilnost rada, } \\
\text { kažnjavanje cestara - primjena }\end{array}$ & & \\
\hline \multirow[t]{2}{*}{3.5.} & Učenici u privredi & \multirow[t]{2}{*}{$1953-1954$} & \multirow[t]{2}{*}{ Kutija 3} \\
\hline & $\begin{array}{l}\text { Učenici u privredi - uključivanje, polaganje ispita za kvalifi- } \\
\text { ciranog radnika }\end{array}$ & & \\
\hline
\end{tabular}

\section{II/4. UNUTRAŠNJI POSLOVI}

\section{Signatura}

Naslov

Vrijeme nastanka gradiva

Razina opisa

Količina i nosač zapisa
HR-DAPA-132/4

Unutrašnji poslovi

1952-1955

Serija

$0,04 \mathrm{~d} / \mathrm{m}$ 
Sadržaj

Plan sređivanja
Serija sadrži razne odluke u svezi s održavanjem javnoga reda i mira u mjestu i dr., raznim okružnicama povezanim s problematikom matičarstva i radom matičarske službe, organizacijom vatrogasne službe i drugom problematikom povezanom uz poslove vatrogastva te zapisnike, saslušanja i odluke u svezi s prekršajnim procesima.

4.1. Opći poslovi

4.2. Matičarstvo

4.3. Civilna zaštita i vatrogastvo

4.4. Administrativno-kazneni poslovi

\section{Popis gradiva serije 4}

\begin{tabular}{|c|c|c|c|}
\hline Signatura & Sadržaj - opis & Godina & $\begin{array}{l}\text { Tehnička } \\
\text { jedinica }\end{array}$ \\
\hline \multirow[t]{2}{*}{4.1.} & Opći poslovi & \multirow[t]{2}{*}{$1952-1955$} & \multirow[t]{2}{*}{ Kutija 4} \\
\hline & $\begin{array}{l}\text { Razne odluke - odluka o javnom redu i noćnom miru, o za- } \\
\text { brani držanja koza u kućanstvu, o zabrani igara za novac i igre } \\
\text { »mora«, dopuna uredbe o prijavljivanju boravka, zapisnik u } \\
\text { predmetu pronađene pokretne imovine, izmjene i dopune odluke } \\
\text { o sajamskom redu, odluka o obveznom čišćenju i špricanju voća- } \\
\text { ka, o održavanju javne čistoće u gradu Pazinu, odluka o stavlja- } \\
\text { nju izvan snage odluka, izmjene i dopune odluka, odluka o odr- } \\
\text { žavanju javne čistoće u gradu Pazinu, promet s našim diplomat- } \\
\text { sko-konzularnim predstavništvima u inozemstvu, nepravilnosti } \\
\text { u adresiranju naših ustanova po talijanskim državnim organima } \\
\text { i državljanima, popis ženske seoske omladine, iseljenici - zaštita } \\
\text { interesa ovdašnje rodbine, karakteristika građana, odluka o pro- } \\
\text { metu i parkiranju motornih i drugih vozila i ostavi tovarne robe, } \\
\text { uputa o organizaciji pazinskih naselja }\end{array}$ & & \\
\hline \multirow[t]{2}{*}{4.2 . } & Matičarstvo & \multirow[t]{2}{*}{$1952 / 1955$} & \multirow[t]{2}{*}{ Kutija 4} \\
\hline & $\begin{array}{l}\text { Okružnice u svezi s matičnim izvodima, izdavanjem potvrda o } \\
\text { biračkom pravu i izvoda iz matične knjige vjenčanih, izradom } \\
\text { pečata matičara, prestankom važenja odredbi iz čl. 53. Zakona } \\
\text { o državnim matičnim knjigama, u svezi s dopunom osnovnoga } \\
\text { zakona o braku, primjenom zakona o matičnim državnim knji- } \\
\text { gama, promjenom osobnih imena i prezimena, rješenjem o pravu } \\
\text { odbornika da pravovaljano prisustvuju pri sklapanju braka }\end{array}$ & & \\
\hline \multirow[t]{2}{*}{4.3.} & Civilna zaštita i vatrogastvo & \multirow[t]{2}{*}{ 1953-1955 } & \multirow[t]{2}{*}{ Kutija 4} \\
\hline & $\begin{array}{l}\text { Organizacija dobrovoljnoga vatrogasnog društva u mjestu, pre- } \\
\text { ventivne mjere - pregledi dimnjaka, organizacija stalne vatroga- } \\
\text { sne službe i straže, primopredaja vatrogasne imovine, zapisnici o } \\
\text { izvršenom pregledu, osiguranje žetve i vršidbe od požara }\end{array}$ & & \\
\hline \multirow[t]{2}{*}{4.4.} & Administrativno-kazneni poslovi & \multirow[t]{2}{*}{$1952-1955$} & \multirow[t]{2}{*}{ Kutija 4} \\
\hline & $\begin{array}{l}\text { Odluka o formiranju komisije za prekršaje pri NOGO-u Pazin, } \\
\text { zapisnici, saslušanja i rješenja u svezi s prijavom štete, dostava } \\
\text { podataka o administrativnim kaznama, izvještaji o prekršaju }\end{array}$ & & \\
\hline
\end{tabular}

\section{II/5. PRIVREDA}




\section{Signatura}

Naslov

Vrijeme nastanka gradiva

Razina opisa

Količina i nosač zapisa

Sadržaj

\section{Plan sređivanja}

HR-DAPA-132/5

Privreda

1952-1955

Serija

2 kutije, $0,2 \mathrm{~d} / \mathrm{m}$

Serija se odnosi na spise koji sadrže tematiku upravljanja privrednim poduzećima, organizacijama i fondovima, zapisnike Savjeta za privredu NOK-a Pazin, izvještaje i podatke o investicijskim projektima, dozvole i rješenja te razne upute za rad obrtnika, spise koji se bave problematikom suzbijanja raznih poljoprivrednih nametnika, priključenjem na vodovodnu mrežu u mjestu, održavanjem šuma te upravljanjem šumskim gospodarstvom, zatim razna rješenja i ovlaštenja za obavljanje trgovinske djelatnosti te okružnice i upute u svezi s trgovinom i opskrbom, analize i planove razvoja turizma i ugostiteljstva te rješenja za otvaranje ugostiteljskih radnji, dozvole i rješenja u svezi s radom poljoprivrednih zadruga, problematikom prijevoza i transporta, prometnim vezama te radom pošte, upute za zaključivanje građevinskih ugovora i građevinske ugovore, građevinske dozvole, dokumentaciju u vezi s tehničkim pregledima, dokumentaciju o javnom nadmetanju, građevinskoj inspekciji, urbanističke planove i nacrte, spise u svezi s elektrifikacijom mjesta, održavanjem groblja, upravljanjem stambenim zgradama, stambenim fondovima i dr.

5.1. Opći poslovi

5.2. Investicije

5.3. Rudarstvo, industrija i obrt

5.4. Poljoprivreda, veterinarstvo, ribarstvo, vodoprivreda i šumarstvo

5.5. Trgovina i opskrba

5.6. Ugostiteljstvo i turizam

5.7. Zadrugarstvo

5.8. Promet

5.9. Građevinarstvo, urbanizam, komunalni i stambeni poslovi

5.9.1. Građevinski i projektantski poslovi

5.9.1.1. Opći poslovi

5.9.1.2. Građevinske dozvole, tehnički pregledi i projektni elaborati

5.9.1.3. Javna nadmetanja, radovi u režiji i ugovori o izvođenju radova

5.9.1.4. Revizija građevinskih projekata

5.9.1.5. Investicijski program

5.9.1.6. Građevinska inspekcija

5.9.1.7. Spisi po broju 
5.9.2. Urbanizam

5.9.3. Komunalni poslovi

5.9.4. Stambeni poslovi

5.9.4.1. Opći poslovi

5.9.4.2. Održavanje stambenoga fonda i evidencija

5.9.4.3. Održavanje i raspodjela zgrada

\section{Popis gradiva serije 5}

\begin{tabular}{|c|c|c|c|}
\hline Signatura & Sadržaj - opis & Godina & $\begin{array}{l}\text { Tehnička } \\
\text { jedinica }\end{array}$ \\
\hline \multirow[t]{2}{*}{5.1.} & Opći poslovi & \multirow[t]{2}{*}{$1952-1955$} & \multirow[t]{2}{*}{ Kutija 4} \\
\hline & $\begin{array}{l}\text { Predaja državnih privrednih poduzeća republičkoga značaja } \\
\text { u nadležnost narodnih odbora, izdvajanje pogona poduzeća, } \\
\text { usklađivanje poduzeća i predaja registra privrednih orga- } \\
\text { nizacija, likvidacija zanatskih radnji, zapisnik sa sjednice i } \\
\text { sastanak članova Savjeta za privredu NOK-a Pazin, molba za } \\
\text { osnivanje fonda za komunalnu izgradnju, odluka o određiva- } \\
\text { nju dimnjačarskih rajona na području Kotara Pazin }\end{array}$ & & \\
\hline \multirow[t]{2}{*}{5.2.} & Investicije & \multirow[t]{2}{*}{$1954-1955$} & \multirow[t]{2}{*}{ Kutija 4} \\
\hline & $\begin{array}{l}\text { Izvještaj o investicijskim radovima, podatci o izvršenim gra- } \\
\text { đevinskim investicijama na području Općine u 1954. godine }\end{array}$ & & \\
\hline \multirow[t]{2}{*}{5.3.} & Rudarstvo, industrija i obrt & \multirow[t]{2}{*}{$1952-1955$} & \multirow[t]{2}{*}{ Kutija 4} \\
\hline & $\begin{array}{l}\text { Popis obrtnika koji posjeduju dozvolu rada, rješenja o odo- } \\
\text { brenju obavljanja obrta, otkaz obrta i prestanak rada, izda- } \\
\text { vanje dozvole rada, izgradnja pekarnice, mjere za suzbijanje } \\
\text { »nadriobrta«, kontrola obrtničkih dozvola, odobrenje ko- } \\
\text { misije za pokretanje dražbi, primjena republičkih zanatskih } \\
\text { propisa - upute }\end{array}$ & & \\
\hline \multirow[t]{2}{*}{5.4.} & $\begin{array}{l}\text { Poljoprivreda, veterinarstvo, ribarstvo, vodoprivreda i šu- } \\
\text { marstvo }\end{array}$ & \multirow[t]{2}{*}{$1952-1955$} & \multirow[t]{2}{*}{ Kutija 4} \\
\hline & $\begin{array}{l}\text { Spisi vezani uz problematiku suzbijanja krumpirove zlatice i } \\
\text { ostalih poljoprivrednih nametnika - organizacija i provedba, } \\
\text { popis čokota vinove loze, popis pasa te obveznoga otkupa } \\
\text { vune, formiranje komisije za procjenu površina i priroda, } \\
\text { spisi vezani uz mjere sprečavanja slinavke i šapa, predaju } \\
\text { šumskoga rasadnika, ubiranje vršaćega ušura (poreza), popis } \\
\text { domaćinstava nastradalih od nevremena, spisi o održavanju } \\
\text { veterinarsko-sanitarnog nadzora na stočnim sajmovima, } \\
\text { rješenje o imenovanju komisije za popis stoke, spisi vezani } \\
\text { uz problematiku priključenja ulica na gradsku vodovodnu } \\
\text { mrežu, rješenje o plaćanju ušura (poreza), dopisi vezani uz } \\
\text { određenje roka za berbu grožđa i dozvolu za sječu šume, } \\
\text { Rezolucija o unapređenju i povećanju poljoprivrede i poljo- } \\
\text { privredne proizvodnje na području NOGO-a Pazin, prijedlog } \\
\text { pregleda kanalizacije, upozorenje vezano uz vršidbu žita, } \\
\text { obavijest o rasporedu vršilica, spisi vezani uz problematiku } \\
\text { osnivanja vodne zajednice, Opća uredba o vodnim zajedni- } \\
\text { cama, odluka o procjeniteljima poljske štete, odluka za izvr- } \\
\text { šenje Zakona o zaštiti poljskih dobara, molba za proširenje }\end{array}$ & & \\
\hline
\end{tabular}




\begin{tabular}{|c|c|c|c|}
\hline & $\begin{array}{l}\text { vodovodne mreže, odluka o postavljanju javnih izljeva za } \\
\text { opskrbu usputnih sela, plan rajonizacije veterinarske službe, } \\
\text { prijedlog proširenja zelenoga pojasa i drvoreda, mjere u cilju } \\
\text { unapređenja poljoprivrede i dr. }\end{array}$ & & \\
\hline \multirow[t]{2}{*}{5.5.} & Trgovina i opskrba & \multirow[t]{2}{*}{$1952-1955$} & \multirow[t]{2}{*}{ Kutija 4} \\
\hline & $\begin{array}{l}\text { Rješenje o osnivanju Pijačne uprave i pijačni red, rješenja } \\
\text { za dozvolu prodaje vina, kupoprodaje raznih proizvoda i } \\
\text { dr., osiguranje opskrbe potrošnje ogrjevom, kontrola rada } \\
\text { mlinova, ovlaštenje o nabavi materijala, sajamski redovi - } \\
\text { usklađenje s ustavom, dopisi vezani uz problematiku otkupa } \\
\text { janjaca po selima te reguliranje prometa stokom, uputa o po- } \\
\text { vlaštenoj kupovini ugljena radnika i službenika zaposlenih u } \\
\text { državnim službama i ustanovama, promjena naziva opskrb- } \\
\text { noga poduzeća, rješenje o odobrenju otvaranja prodavaonice } \\
\text { u Pazinu, upute i nadležnost za izdavanje stočnih putnica } \\
\text { te nedopuštena trgovina, odobrenje obavljanja trgovinske } \\
\text { djelatnosti na veliko, suglasnost o preuzimanju skladišta na } \\
\text { željezničkoj postaji u Pazinu }\end{array}$ & & \\
\hline \multirow[t]{2}{*}{5.6.} & Ugostiteljstvo i turizam & \multirow[t]{2}{*}{$1952 / 1955$} & \multirow[t]{2}{*}{ Kutija 4} \\
\hline & $\begin{array}{l}\text { Rješenje o komisiji za pregled i analize poslovanja u Grad- } \\
\text { skom ugostiteljskom poduzeću u Pazinu, upute u svezi s da- } \\
\text { vanjem oglasa, problematika rada benzinskih crpki, dozvola } \\
\text { za otvaranje privatne ugostiteljske radnje, izvod iz zapisnika } \\
\text { sa sjednice Radničkoga savjeta Ugostiteljskog poduzeća } \\
\text { »Ucka« u Pazinu, dopis u svezi s planom razvoja turizma }\end{array}$ & & \\
\hline \multirow[t]{2}{*}{5.7.} & Zadrugarstvo & \multirow[t]{2}{*}{$1952-1955$} & \multirow[t]{2}{*}{ Kutija 4} \\
\hline & $\begin{array}{l}\text { Davanje vinarskih podruma i sušionice duhana poljoprivred- } \\
\text { noj zadruzi, rješenja o odobrenju otvaranja prodavaonice i } \\
\text { gostionice Poljoprivrednoj zadruzi Pazin, dodjela državnih } \\
\text { objekata za usklađivanje poljoprivrednih dobara u školi, } \\
\text { odobrenje obavljanja rada mlina Poljoprivrednoj zadruzi } \\
\text { Sv. Petar u Šumi, dopisi u svezi s djelovanjem zadruga, za- } \\
\text { hvalnica u svezi s dovršenjem zadružnoga doma, dozvola } \\
\text { Poljoprivredne zadruge Rovinj za rad na području NOGO-a } \\
\text { Pazin, nalog za dovršenje vršidbe u Kršikli }\end{array}$ & & \\
\hline \multirow[t]{2}{*}{5.8.} & Promet & \multirow[t]{2}{*}{$1952-1955$} & \multirow[t]{2}{*}{ Kutija 4} \\
\hline & $\begin{array}{l}\text { Dopisi vezani uz problematiku postavljanja prometnih } \\
\text { znakova i obavljanje javnoga prijevoza roba i putnika od } \\
\text { strane voznih parkova privrednih i društvenih organizacija, } \\
\text { okružnica Privrednoga savjeta NRH o poslovima prometa, } \\
\text { prijedlog za otvaranje poštanskoga ureda u Gračišću, auto- } \\
\text { busna veza s mjestom Lindar, obavljanje transportnih usluga, } \\
\text { primjedbe na rad pošte u Pićnu, dostava pošte u Škopljak, } \\
\text { ugovori o prijevozu, dozvola za obavljanje prijevoza robe i } \\
\text { putnika u javnom cestovnom prometu, rješenje o cestovnom } \\
\text { prometu, dopis Željezničkoga transportnog poduzeća Lju- } \\
\text { bljana, uža dostava područja pošte - podatci }\end{array}$ & & \\
\hline 5.9. & Građevinarstvo, urbanizam, komunalni i stambeni poslovi & & Kutija 5- \\
\hline
\end{tabular}




\begin{tabular}{|c|c|c|c|}
\hline 5.9.1. & Građevinski i projektantski poslovi & & \multirow[t]{14}{*}{ Kutija 5} \\
\hline \multirow[t]{2}{*}{ 5.9.1.1. } & Opći poslovi & \multirow[t]{2}{*}{$1953-1954$} & \\
\hline & $\begin{array}{l}\text { Uputa za zaključivanje ugovora s građevinskim poduzećima, } \\
\text { naredba o pokretanju radova na akord }\end{array}$ & & \\
\hline 5.9.1.2. & Građevinske dozvole, tehnički pregledi i projektni elaborati & & \\
\hline 5.9.1.2.1. & Rješenja o građevinskoj dozvoli, tehnički opisi, nacrti i dr. & 1954 & \\
\hline 5.9.1.2.2. & $\begin{array}{l}\text { Tehnički pregledi, opisi, nacrti, izvještaji, zapisnici i rješenja } \\
\text { komisije za tehnički pregled i projektni elaborati }\end{array}$ & $1953-1954$ & \\
\hline 5.9.1.3. & $\begin{array}{l}\text { Javna nadmetanja, radovi u režiji i ugovori o izvođenju ra- } \\
\text { dova }\end{array}$ & 1954 & \\
\hline 5.9.1.3.1. & $\begin{array}{l}\text { Zapisnici o ponudi i nadmetanju komisija za dražbu te za } \\
\text { preuzimanje stolarskih radova, zapisnici o izvršenim ra- } \\
\text { dovima, produljenje roka za izvršenje radova, postavljanje } \\
\text { nadzornoga organa na gradilištu, produženje ugovora i pri- } \\
\text { mjedbe u svezi s gradnjom }\end{array}$ & 1954 & \\
\hline 5.9.1.3.1. & $\begin{array}{l}\text { Zapisnici o ponudi i nadmetanju komisija za dražbu te za } \\
\text { preuzimanje stolarskih radova, zapisnici o izvršenim ra- } \\
\text { dovima, produljenje roka za izvršenje radova, postavljanje } \\
\text { nadzornoga organa na gradilištu, produženje ugovora i pri- } \\
\text { mjedbe u svezi s gradnjom }\end{array}$ & 1954 & \\
\hline 5.9.1.3.2. & Ugovori o izvođenju radova & 1954 & \\
\hline \multirow[t]{2}{*}{ 5.9.1.4. } & Revizija građevinskih projekata & \multirow[t]{2}{*}{1954} & \\
\hline & Revizija i odobrenje projekta vodovoda za Beram & & \\
\hline \multirow[t]{2}{*}{ 5.9.1.5. } & Investicijski program & \multirow[t]{2}{*}{1954} & \\
\hline & Perspektivni plan investicijske izgradnje & & \\
\hline \multirow[t]{2}{*}{ 5.9.1.6. } & Građevinska inspekcija & \multirow[t]{2}{*}{1954} & \multirow[t]{4}{*}{ Kutija 5} \\
\hline & $\begin{array}{l}\text { Uviđaj u svrhu određivanja lokacije nove zgrade kotara, trga } \\
\text { i ostalih objekata }\end{array}$ & & \\
\hline \multirow[t]{2}{*}{ 5.9.1.7. } & Spisi po broju & \multirow[t]{2}{*}{$1952-1955$} & \\
\hline & $\begin{array}{l}\text { Pregled terena radi dodjele gradnje i rješenje o lokaciji, } \\
\text { objašnjenje za odobrenje gradnji na području narodnih od- } \\
\text { bora općina, razna odobrenja za gradnju građanima, usta- } \\
\text { novama i privrednim organizacijama, hitni popravci zgrada } \\
\text { - izvještaj i trebovanje kredita, odluke o rušenju zgrade, } \\
\text { ugovori za projektni elaborat, uredbe o građenju, rješenja o } \\
\text { široj i užoj lokaciji za gradnju, izvještaj o tehničkim pregle- } \\
\text { dima izvedenih radova, ugovori vezani uz adaptaciju zgrada, } \\
\text { perspektivni plan investicijske izgradnje, revizija elaborata i } \\
\text { obustava gradnje }\end{array}$ & & \\
\hline \multirow[t]{2}{*}{5.9 .2 . } & Urbanizam & \multirow[t]{2}{*}{ 1953-1954 } & \multirow[t]{2}{*}{ Kutija 6} \\
\hline & $\begin{array}{l}\text { Dostava katastarskih karata, upute za uređenje parka, anali- } \\
\text { tički podatci za izradu idejnoga urbanističkog nacrta, izrada } \\
\text { klupa za parkove, očevid u Pazinu }\end{array}$ & & \\
\hline
\end{tabular}




\begin{tabular}{|c|c|c|c|}
\hline \multirow{2}{*}{ 5.9.3. } & Komunalni poslovi & \multirow{2}{*}{$1952-1955$} & \multirow{2}{*}{ Kutija 6} \\
\hline & $\begin{array}{l}\text { Spisi vezani uz problematiku elektrifikacije sela, zahtjev za } \\
\text { promjenom javnog natpisa, odluka o odstranjivanju ruševi- } \\
\text { na, molba za pronalaskom krivca oštećenja znakova na cesti, } \\
\text { opći upitnik za komunalne ustanove i radne grupe, spisi ve- } \\
\text { zani uz problematiku odluke izgradnje i održavanja mjesnih } \\
\text { putova, mostova, sezonskih prolaza i dr., opći podatci o ko- } \\
\text { munalnim djelatnostima, spisi vezani uz problematiku rado- } \\
\text { va na javnim cisternama i vrelima u 1953. godini, osnivanja } \\
\text { novih grobalja i upravljanja grobljima, održavanje putova } \\
\text { pomoću obveznoga besplatnog rada, uređenje staničnoga } \\
\text { prostora i prilaznoga puta, popravak i uređenje javne rasvje- } \\
\text { te, izgradnju trafostanice u Sv. Petru u Šumi i niskonaponske } \\
\text { mreže za selo Heki i okolicu, dozvola za uređenje terase } \\
\text { hotela, spisi vezani uz izmjenu električnog voda, ugovori o } \\
\text { stolarskim radovima, spis vezan uz problematiku uređenja } \\
\text { pazinske jame, izvadak iz uredba o zaštiti javnih putova, } \\
\text { izvještaj o popravku krova zgrade pošte u Pazinu, traženje } \\
\text { raspodjele stolarije, podatci i izvješce o boksitnim jamama, } \\
\text { prijedlozi vezani uz obnovu spaljenih kuća, rješenja vezana } \\
\text { uz adaptaciju i rušenje objekata }\end{array}$ & & \\
\hline 5.9 .4 . & Stambeni poslovi & \multirow[t]{3}{*}{$1952-1955$} & \multirow[t]{8}{*}{ Kutija 6} \\
\hline \multirow[t]{2}{*}{ 5.9.4.1. } & Opći poslovi & & \\
\hline & $\begin{array}{l}\text { Odluke, izmjene i dopune odluka te razne upute o reguli- } \\
\text { ranju najamnine i otkaza za stanove i poslovne prostorije, o } \\
\text { raspodjeli fonda za održavanje zgrada, o propisima o izda- } \\
\text { vanju poslovnih prostorija u zakup, o organima upravljanja } \\
\text { stambenim zgradama, o utvrđivanju stambenih zona i ele- } \\
\text { mentima o kategorizaciji stanova, o uvjetima zaključivanja } \\
\text { ugovora o korištenju stanova, o stambenoj tarifi i raspodjeli } \\
\text { stanarina, o prodaji stambenih zgrada i upravljanju stambe- } \\
\text { nim zgradama, o prodavanju manjih stambenih zgrada iz } \\
\text { općenarodne imovine, rješenja o imenovanju stambene in- } \\
\text { spekcije i vršitelja dužnosti šefa stambene zajednice NOGO- } \\
\text { a Pazin, uputa o uključenju stambenih zgrada u stambenu } \\
\text { zajednicu, podatci o stambenom upravljanju }\end{array}$ & & \\
\hline \multirow[t]{2}{*}{ 5.9.4.2. } & Održavanje stambenoga fonda i evidencija & \multirow[t]{2}{*}{1954} & \\
\hline & $\begin{array}{l}\text { Podatci o vojnim zgradama te nekretninama JNA - upravlja- } \\
\text { nje stambenim fondom }\end{array}$ & & \\
\hline 5.9.4.3. & Održavanje i raspodjela zgrada & & \\
\hline 5.9.4.3.1. & $\begin{array}{l}\text { Molbe i rješenja o dodjeli stana i prostorija, zamjeni stana, } \\
\text { kupoprodaji stana, popravku stambenih zgrada; spisi o pre- } \\
\text { gledu i procjeni stanova, traženje proširenja lokala, rješenje } \\
\text { o imenovanju stambene komisije, izvještaji o stambenom } \\
\text { pitanju i dr. }\end{array}$ & $1952-1955$ & \\
\hline 5.9.4.3.2. & $\begin{array}{l}\text { Procjena zgrada, opisi nekretnina, komisijski pregledi sta- } \\
\text { nova }\end{array}$ & 1954 & \\
\hline
\end{tabular}




\section{II/6. FINANCIJE}

\section{Signatura \\ Naslov \\ Vrijeme nastanka gradiva \\ Razina opisa \\ Količina ì nosač zapisa \\ Sadržaj}

\section{Plan sređivanja}

\author{
HR-DAPA-132/6 \\ Financije \\ 1952-1955 \\ Serija
}

1 i $1 / 2$ kutije, $0,15 \mathrm{~d} / \mathrm{m}$

Serija sadrži spise u svezi s računovodstvenim poslovima i materijalnim poslovanjem, završne račune, prihode i rashode, poslove proračunske službe, raspolaganje sredstvima fondova, dotacije, odobrenje i raspolaganje kreditima i zajmovima, financijsko poslovanje ustanova sa samostalnim financiranjem, razne upute i odluke u svezi s upravljanjem porezima i prihodima, platne liste, zapisnike procjene nekretnina, problematiku povezanu s kolonatskim odnosima i upravljanjem općenarodnom imovinom te poslove u svezi s katastrom i snimanjem zemljišta.

6.1. Opći poslovi

6.2. Proračun i završni račun

6.3. Fondovi

6.4. Dotacije

6.5. Krediti, pozajmice i jamstva

6.6. Ustanove sa samostalnim financiranjem

6.7. Prihodi od privrede i stanovništva

6.8. Imovinsko-pravni poslovi

6.9. Geodetsko-katastarski poslovi

\section{Popis gradiva serije 6}

\begin{tabular}{|l|l|l|l|}
\hline Signatura & Sadržaj - opis & Godina & $\begin{array}{l}\text { Tehnička } \\
\text { jedinica }\end{array}$ \\
\hline 6.1. & $\begin{array}{l}\text { Opći poslovi } \\
\text { Sankcije u slučaju isplata bez suglasnosti, rješenje o pravu } \\
\text { raspolaganja računom, rashodovanje inventara i materijala kod } \\
\text { proračunskih ustanova, komisija za popis inventara i materijala } \\
\text { NOGO-a Pazin }\end{array}$ & $1954-1955$ & Kutija 6 \\
\hline 6.2. & $\begin{array}{l}\text { Proračun i završni račun } \\
\text { Osiguranje materijalnih sredstava društava i ustanova, završni } \\
\text { račun za 1951. godinu, likvidacija obveza po proračunu, orga- } \\
\text { nizacija proračunske službe i osnivanje računske komisije u } \\
\text { NO-ima, razni proračunski planovi, planiranje prihoda i rasho- } \\
\text { da, pregled rashoda, prijedlog proračuna i prijedlog dopunskog } \\
\text { proračuna, podatci o brojnom stanju službenika, odluka o } \\
\text { privremenom financiranju NOGO-a, odluka o odobrenju za- } \\
\text { vršnoga računa i izvršenju proračuna NOGO -a Pazin; Stalna } \\
\text { konferencija gradova i gradskih općina FNRJ - podatci o visini } \\
\text { proračuna NOGO-a Pazin, izvještaj o ostvarenju i izvršenju } \\
\text { proračuna, upute za sastav završnoga računa }\end{array}$ & Kutija 6 \\
\hline
\end{tabular}




\begin{tabular}{|c|c|c|c|}
\hline \multirow[t]{2}{*}{6.3.} & Fondovi & \multirow[t]{2}{*}{$1953-1954$} & \multirow[t]{2}{*}{ Kutija 6} \\
\hline & $\begin{array}{l}\text { Dodjela novca fondovima i zadrugama; Fond za samostalno } \\
\text { raspolaganje - dodjele iznosa, naplaćivanje doprinosa za fond } \\
\text { za unapređenje poljoprivrede }\end{array}$ & & \\
\hline \multirow[t]{2}{*}{6.4 . } & Dotacije & \multirow[t]{2}{*}{$1953-1955$} & \multirow[t]{2}{*}{ Kutija 6} \\
\hline & Razne dotacije i novčane pomoći poduzećima i projektima & & \\
\hline \multirow[t]{2}{*}{6.5 . } & Krediti, pozajmice i jamstva & \multirow[t]{2}{*}{ 1952-1955 } & \multirow[t]{2}{*}{ Kutija 6} \\
\hline & $\begin{array}{l}\text { Molbe i rješenja o dodjeli dugoročnih zajmova i kredita, odo- } \\
\text { brenju kredita, naplati zaostalih anuiteta na zajmove, sniženju } \\
\text { i povećanju kredita, molbe i odobrenja investicijskoga zajma, } \\
\text { odobrenje virmana kredita, odluka o dodjeli i raspodjeli kredita } \\
\text { za obnovu popaljenih kuća, odluka o odobrenju sredstava za } \\
\text { isplatu kamata i anuiteta, raspodjela akreditiva za održavanje } \\
\text { škole, pravdanje kredita, povećanje akreditiva i dr. }\end{array}$ & & \\
\hline 6.6 . & Ustanove sa samostalnim financiranjem & & \multirow[t]{3}{*}{ Kutija 6} \\
\hline 6.6 .1$. & $\begin{array}{l}\text { Spisi po broju: upute za provedbu Uredbe o ustanovama sa } \\
\text { samostalnim financiranjem, pravo potpisa i registracija ustano- } \\
\text { ve, imenovanje komisije za izvršenje inventure skladišta, likvi- } \\
\text { dacije ustanova sa samostalnim financiranjem, likvidacijska } \\
\text { komisija }\end{array}$ & $1952 / 1955$ & \\
\hline 6.6.2. & Završni računi ustanova sa samostalnim financiranjem & $1953-1954$ & \\
\hline 6.7. & Prihodi od privrede i stanovništva & & \multirow[t]{4}{*}{ Kutija 7} \\
\hline 6.7.1. & $\begin{array}{l}\text { Spisi po broju: brisanje poduzeća iz registra, imenovanje člano- } \\
\text { va komisije za provjeru prihoda, upute o rješavanju žalbi protiv } \\
\text { poreznih rješenja, razne okružnice Ministarstva financija, } \\
\text { Uprave prihoda u Zagrebu i Uprave financija, NOGO-a Pazin, } \\
\text { evidencija poreza na promet proizvoda, odluke o naplaćivanju } \\
\text { taksa i poreza, knjiženje ovršnih troškova, prijedlog razreza po- } \\
\text { reza, naplata kamata, porez na honorare državnih službenika, } \\
\text { naplata poreza po katastarskom prihodu, objašnjenje poreza na } \\
\text { promet, izračunavanje katastarskoga prihoda, Narodna banka } \\
\text { - plaćanje taksa, propis Uredbe o raspodjeli ukupnoga prihoda } \\
\text { privrednih organizacija, naplata poreza na dohodak, odluke o } \\
\text { općinskom prirezu i porezu }\end{array}$ & $1952-1955$ & \\
\hline 6.7.2. & Završni računi privrednih organizacija & 1954 & \\
\hline 6.7.3. & Platne liste & $1952-1955$ & \\
\hline \multirow[t]{2}{*}{6.8.} & Imovinsko-pravni poslovi & \multirow[t]{2}{*}{$1952-1955$} & \multirow[t]{2}{*}{ Kutija 7} \\
\hline & $\begin{array}{l}\text { „Spisak lica koja su podnijela prijave potraživanja prema Nje- } \\
\text { mačkoj zbog neplaćenog rada«, komisija i zapisnici procjene } \\
\text { nekretnina, kontrola prometa nepokretnosti, odluka u svezi sa } \\
\text { zauzimanjem zemljišta, podatci o zemljištu, otuđenje zemljišta } \\
\text { i zgrada iz fonda općenarodne imovine, oduzimanje zemljišta, } \\
\text { dodjela zemljišta iz fonda općenarodne imovine, potvrda o ne- } \\
\text { kretninama, prijenosi poljoprivrednih zemljišta, rješenje o do- } \\
\text { djeli grobnih mjesta, eksproprijacijska komisija, eksproprijacija }\end{array}$ & & \\
\hline
\end{tabular}




\begin{tabular}{|l|l|l|}
\hline & $\begin{array}{l}\text { nekretnina, darovni ugovor, otkazi korištenja zemljišta, ugo- } \\
\text { vori i rješenja o zakupu zemljišta, rješenje o određenju organa } \\
\text { upravljanja zemljištem, razrješenje kolonatskoga odnosa, ime- } \\
\text { novanje Komisije za agrarna pitanja, pravno stanje zemljišta na } \\
\text { kojem su građene javne zgrade, poništenje dražbe nekretnina, } \\
\text { zamjena zemljišta općenarodne imovine, razrješenje napoličar- } \\
\text { skoga odnosa, oduzimanje rasadnika, prijenos nepokretne imo- } \\
\text { vine talijanskih optanata i nacionalizirane imovine talijanskih } \\
\text { državljana u općenarodnu imovinu, stanje evidencije zemljišno- } \\
\text { ga fonda, odobrenje kupoprodajnoga ugovora }\end{array}$ & \\
\hline 6.9. & $\begin{array}{l}\text { Geodetsko-katastarski poslovi } \\
\text { Revizija katastra na području Općine Pazin, radovi geodetskih } \\
\text { stručnjaka ureda za katastar po traženju ustanova, poduzeća i } \\
\text { privatnika, obnova klasiranja zemljišta - imenovanje članova } \\
\text { komisije, snimanje zemljišta kod zgrade Narodne milicije, do- } \\
\text { stava zapisnika radi promjene katastarskoga operata }\end{array}$ & $1952-1955$ \\
\hline
\end{tabular}

\section{II/7. ZDRAVSTVO I SOCIJALNA ZAŠTITA}

Signatura
Naslov
Vrijeme nastanka gradiva
Razina opisa
Količina i nosač zapisa
Sadržaj

\section{Plan sređivanja}

\author{
HR-DAPA-132/7 \\ Zdravstvo i socijalna zaštita \\ 1952-1955 \\ Serija \\ $0,02 \mathrm{~d} / \mathrm{m}$
}

Serija se sastoji od predmeta u svezi sa socijalnom zaštitom obitelji i odraslih osoba, ratnih vojnih i civilnih invalida te raznih socijalno ugroženih slučajeva. Također sadrži spise u svezi s problematikom zdravstvene zaštite, sanitarne higijene, radom zdravstvenih i socijalnih ustanova, zapisnike Savjeta za narodno zdravlje i socijalnu politiku i dr.

Gradivo je kronološki poredano.

Popis gradiva serije 7

\begin{tabular}{|l|l|l|l|}
\hline Signatura & Sadržaj - opis & Godina & $\begin{array}{l}\text { Tehnička } \\
\text { jedinica }\end{array}$ \\
\hline 7. & $\begin{array}{l}\text { Predmeti u svezi s invalidninom, upute u svezi s naplatom } \\
\text { dječjega dodatka, osposobljavanje invalida za školsku godinu, } \\
\text { primanje pitomaca od strane Zavoda za slijepe, prestanak isplate } \\
\text { nagrada i industrijskih bonova ratnim vojnim invalidima, zdrav- } \\
\text { stvena zaštita eksperata OUN-a, zabrana djelovanja skladišta, } \\
\text { prijava trovanja hranom, upute u svezi s invalidskim dodatkom, }\end{array}$ & $1952-1955$ & Kutija 8 \\
\hline
\end{tabular}




\begin{tabular}{|l|l|l|}
\hline zdravstvena zaštita korisnika invalidnine, invalidski dodatci - \\
objašnjenje, sanitarna higijena, status ljekarni, upute u svezi s \\
prijenosom mrtvaca, pripojenje Odjela za borbu protiv TBC-a \\
Centralnom higijenskom zavoju, podatci u svezi sa zaposlenim \\
primaocima invalidske mirovine, planiranje sredstava za skrb- \\
ništvo, referat o situaciji administrativne izvanbolničke službe, \\
pitanje poslovanja zdravstvenih ustanova, jačanje suradnje i \\
pružanje pomoći u radu lokalnim zavodima za socijalno osigu- \\
ranje, mrtvozornička služba - upute i statistika, podatci o radu \\
naših državljana u inozemstvu, pomoći za nezaposlene, isplate \\
plaća osobama koje se nalaze na vojnoj vježbi JNA, materijalna \\
pomoć preživjelim žrtvama medicinskih eksperimenata u kon- \\
centracijskim logorima i popis osoba, izvješće mrtvozornika i \\
mrtvozorničke službe, uspostavljanje laičke kontrole, poveća- \\
nje stope doprinosa za socijalno osiguranje, isplata novčanih \\
certifikata izdanih po Armiji Velike Britanije/Engleske bivšim \\
zarobljenicima engleske vojske te popis osoba, otklanjanje higi- \\
jenskih nedostataka, obustava prometa lijekova, smještaj djece \\
u dječjim domovima - obitelji, upute za prijavljivanje prekršaja i \\
drugih povreda zakona, osnivanje Udruženja socijalnih radnika \\
FNRJ, prekvalifikacija ratnih vojnih invalida, Zapisnik o sa- \\
stanku Savjeta za narodno zdravlje i socijalnu politiku NOGO-a \\
Pazin iz 1955. godine, Odluka o osnivanja fonda za pomoć djeci \\
poginulih boraca i žrtava fašističkoga terora, materijalno osigu- \\
ranje bivših vlasnika ljekarni i njihovih obitelji, dodjela pomoći \\
primaljama
\end{tabular} \mid

\section{II/8. PROSVJETA I KULTURA}

Signatura

Naslov

Vrijeme nastanka gradiva

Razina opisa

Količina i nosač zapisa

Sadržaj

\section{Plan sređivanja}

\author{
HR-DAPA-132/8 \\ Prosvjeta i kultura \\ 1952-1955 \\ Serija \\ $0,02 \mathrm{~d} / \mathrm{m}$
}

Serija sadrži spise u svezi s kulturno-prosvjetnom problematikom, izvješća o ustanovama predškolskoga i izvanškolskog odgoja te izvještaje sjednica Kotarskoga vijeća, spise u svezi s radom raznih kulturnih ustanova, dopise Savjeta za prosvjetu, znanost i kulturu NR Hrvatske, upise u škole te otvaranje novih škola i smjerova, spise u svezi s radom školskih savjeta te savjeta za prosvjetu i kulturu, razne tečajeve za odrasle, stipendiranje studenata, organiziranje proslava i proglašenje praznika, izvještaje s odgojno-obrazovnih kongresa i dr. Gradivo je kronološki poredano. 


\section{Popis gradiva serije 8}

\begin{tabular}{|c|c|c|c|}
\hline Signatura & Sadržaj - opis & Godina & $\begin{array}{l}\text { Tehnička } \\
\text { jedinica }\end{array}$ \\
\hline 8. & $\begin{array}{l}\text { Izvještaj o ostanku ustanova predškolskoga i izvanškolskog } \\
\text { odgoja pod rukovodstvom Savjeta za prosvjetu i kulturu, akcija } \\
\text { pomoći muzeju, dopisi Ogranka Seljačke sloge, rješenje o po- } \\
\text { stavljanju vrtuljka u Pazinu, popisi ženske omladine, izvještaj i } \\
\text { zapisnik sjednice Kotarskoga vijeća iz 1953. o kulturno-prosvjet- } \\
\text { nim problemima Kotara, dopis Savjeta za prosvjetu, znanost i } \\
\text { kulturu NR Hrvatske, upis u trogodišnju zanatsku školu, pitanje } \\
\text { smještaja knjižare i njeno likvidiranje, otvaranje novih osmogo- } \\
\text { dišnjih škola i novih viših razreda gimnazije, otkup djela likovne } \\
\text { umjetnosti, dozvola održavanja tečajeva, stipendiranje apsolve- } \\
\text { nata fakulteta, preuzimanje instrumenata limene glazbe, zaklju- } \\
\text { čak o izboru, broju i sastavu školskih savjeta, određivanje pred- } \\
\text { stavnika u školskim savjetima, pronalazak učenika za pčelarsku } \\
\text { školu, konferencije školskih savjeta i zapisnici sastanaka, popis } \\
\text { nepismenih građana, nastavni plan politehničkoga obrazovanja, } \\
\text { dozvola za rad zabavišta, izvještaj s II. kongresa Narodne teh- } \\
\text { nike Hrvatske - Saveza za tehnički odgoj, organizacija proslave } \\
\text { dana »dječje radosti«, odluka o proglašenju 9. svibnja narodnim } \\
\text { praznikom na području gradske općine Pazin }\end{array}$ & $1952-1955$ & Kutija 8 \\
\hline
\end{tabular}

\section{II/9. PRAVOSUĐE}

Signatura
Naslov
Vrijeme nastanka gradiva
Razina opisa
Količina i nosač zapisa
Sadržaj

\section{Plan sređivanja}

\section{HR-DAPA-132/9}

Pravosuđe

$1952-1955$

Serija

$0,02 \mathrm{~d} / \mathrm{m}$

Serija sadrži spise u svezi s problematikom građansko-pravnih potraživanja te razne pravne propise, postupke i odluke Kotarskoga suda u Pazinu i Okružnoga suda u Puli u svezi s raznim parničnim i izvanparničnim predmetima te uknjižbu nekretnina u zemljišnim knjigama.

9.1. Opći poslovi

9.2. Postupci i odluke

9.3. Zemljišno-knjižni poslovi

\section{Popis gradiva serije 9}

\begin{tabular}{|l|l|l|l|}
\hline Signatura & Sadržaj - opis & Godina & $\begin{array}{l}\text { Tehnička } \\
\text { jedinica }\end{array}$ \\
\hline \multirow{2}{*}{ 9.1. } & Opći poslovi & 1952 & Kutija 8 \\
\cline { 2 - 3 } & $\begin{array}{l}\text { Utvrđivanje, osiguranje i naplata građansko-pravnih potraži- } \\
\text { vanja, popis općih pravnih propisa }\end{array}$ & \\
\hline
\end{tabular}




\begin{tabular}{|c|c|c|c|}
\hline \multirow[t]{2}{*}{9.2 . } & Postupci i odluke & \multirow[t]{2}{*}{$1952-1955$} & \multirow[t]{2}{*}{ Kutija 8} \\
\hline & $\begin{array}{l}\text { Rješenja Kotarskoga suda u Pazinu i Okružnoga suda u Puli, } \\
\text { razne presude i rješenja tužbi, parnični i izvanparnični pred- } \\
\text { meti, ovlaštenja za zastupanje u sporu, spor u svezi s potro- } \\
\text { šačkim kartama, privremeno oduzimanje stambenih prostori- } \\
\text { ja Župnom uredu u Grdoselu, rasporedna rješenja za članove } \\
\text { zadruga, spor oko poljske štete, dozvola sklapanja braka, spor } \\
\text { oko prodaje pokretnina i dr. }\end{array}$ & & \\
\hline \multirow[t]{2}{*}{9.3.} & Zemljišno-knjižni poslovi & \multirow[t]{2}{*}{$1952-1955$} & \multirow[t]{2}{*}{ Kutija 8} \\
\hline & $\begin{array}{l}\text { Rješenja o raspisu, otpisu i uknjižbi katastarskih čestica, rje- } \\
\text { šenja o uknjižbi nekretnina kao općenarodne imovine, do- } \\
\text { zvola uknjižbe prava zaloga za nekretnine, upis u zemljišnim } \\
\text { knjigama konfiscirane nekretnine, prilozi uz uknjižbu nekret- } \\
\text { nina, zemljišno-knjižni prijenos prodanih nekretnina, upis } \\
\text { organa upravljanja nekretninama, rješenje o upisu odreknuća } \\
\text { od nekretnina i dr. }\end{array}$ & & \\
\hline
\end{tabular}

\section{II/10. NARODNA OBRANA}

Signatura

Naslov

Vrijeme nastanka gradiva

Razina opisa

Količina i nosač zapisa

Sadržaj

Plan sređivanja
HR-DAPA-132/10

Narodna obrana

1953-1954

Serija

$0,01 \mathrm{~d} / \mathrm{m}$

Serija sadrži spise u svezi s problematikom mobilizacije te predvojničke obuke i novačenja.

10.1. Organizacijsko-mobilizacijski poslovi

10.2. Predvojnička obuka i novačenje

\section{Popis gradiva serije 10}

\begin{tabular}{|l|l|l|l|}
\hline Signatura & Sadržaj - opis & Godina & $\begin{array}{l}\text { Tehnička } \\
\text { jedinica }\end{array}$ \\
\hline \multirow{2}{*}{ 10.1. } & Organizacijsko-mobilizacijski poslovi & 1953 & Kutija 8 \\
\cline { 2 - 4 } & $\begin{array}{l}\text { Izvještaj o stanju mobilizacijskih planova Općine Pazin (strogo } \\
\text { povjerljiva arhiva) }\end{array}$ & $1953-1954$ & Kutija 8 \\
\hline 10.2. & \begin{tabular}{l} 
Predvojnička obuka i novačenje \\
\cline { 2 - 4 }
\end{tabular} & $\begin{array}{l}\text { Postavljanje komandira vodova, rješenje i izvještaji o jesenskom } \\
\text { zborovanju seoske omladine, rješenja i naredbe o zborovanju } \\
\text { omladine u svezi s predvojničkom vojnom obukom te izvještaji o } \\
\text { predvojničkoj obuci, podatci o bijegu regruta Aničeta Balde }\end{array}$ & \\
\hline
\end{tabular}




\section{SAŽETAK}

\section{Sumarni inventar fonda Narodni odbor gradske općine Pazin 1952. - 1955.}

Narodni odbor gradske općine Pazin osnovan je u travnju 1952. ukinućem dotadašnjih mjesnih narodnih odbora Pazin, Gračišće, Kašćerga, Katun Trviški i Sveti Petar u Šumi čije područje nadležnosti prelazi pod novoosnovani Narodni odbor gradske općine Pazin. Djelovao je do kraja kolovoza 1955. kad se novim administrativnim preustrojem ukidaju gradske općine te prelaze u novoosnovane općine. Ukinućem Narodnoga odbora gradske općine Pazin osnovan je Narodni odbor Općine Pazin koji preuzima mjesnu nadležnost ukinutoga stvaratelja. Narodnom odboru gradske općine Pazin hijerarhijski je bio nadređen Narodni odbor kotara Pazin.

Narodni odbor gradske općine bio je zadužen za obavljanje poslova izvršne djelatnosti u svezi s privrednim, komunalnim, socijalnim i kulturnim razvitkom gradske općine. Za proučavanje pojedinih pitanja i pripremanje zaključaka te vršenje anketa vijeća Narodni odbor gradske općine formirao je stalne i povremene komisije. Za izvršenje zakona i propisa Narodnoga odbora i viših državnih organa te obavljanje upravnih poslova osnivali su se savjeti. Za pripremu i izvršenje poslova iz svoje nadležnosti Narodni odbor gradske općine imao je svoju administraciju kojoj je na čelu bio tajnik. O izvršenju odluka i drugih akata, mjera Narodnoga odbora i propisa viših državnih organa te usklađivanju rada svih organa Narodnoga odbora, i uz nadzor administracije, brinuo se predsjednik Narodnoga odbora.

Nakon prestanka rada stvaratelja gradivo je ostalo u posjedu sljednika sve dok nije od Skupštine Općine Pazin preuzeto u Arhiv u dvama navratima, 1972. i 1973. godine, te je okvirno sređeno, evidentirano i izdvojeno od gradiva povezanih stvaratelja. Arhivistička je obrada obavljena tijekom 2016. godine, a u rujnu je iste godine izrađen i Sumarni inventar. Gradivo je sređeno sukladno sadržajno-funkcionalnom modelu sređivanja prema kojemu su formirane pojedine serije. Fond se sastoji od deset osnovnih serija: Registraturna pomagala, Opći poslovi, Rad i radni odnosi, Unutrašnji poslovi, Privreda, Financije, Zdravstvo i socijalna zaštita, Prosvjeta i kultura, Pravosuđe i Narodna obrana. Na nižim su razinama strukture formirane podserije i podpodserije, a gradivo je na najnižoj razini kronološki posloženo. 


\section{SUMMARY \\ The Summary Inventory of the Fonds of the People's Committee of the Pazin Town Municipality 1952 - 1955}

The People's Committee of the Pazin Town Municipality was founded in April 1952 following the abolition of the Local People's Committees of Pazin, Gračišće, Kašćerga, Katun Trviški and Sveti Petar u Šumi, whose jurisdiction was transferred to the newly established People's Committee of the Pazin Town Municipality. This was active until the end of August 1955, when the new administrative reform abolished the town municipalities, which turned into the newly established municipalities. After the abolition of the People's Committee of the Town Municipality of Pazin, the People's Committee of the Pazin Municipality was established, which assumed the local authority of the abolished creator. The People's Committee of the Pazin Town Municipality was hierarchically subordinate to the People's Committee of the Pazin District.

The People's Committee of the Town Municipality was in charge of executive affairs in connection with the economic, infrastructural, social and cultural development of the Town Municipality. For the purpose of studying individual issues and preparing conclusions and conducting a survey of the council, the People's Committee of the Town Municipality established permanent and occasional commissions. Councils were set up for the execution of the laws and regulations of the People's Committee and higher state authorities and for the conduct of administrative affairs. The People's Committee of the Town Municipality had its own administration, headed by a secretary, to prepare and implement the tasks within its competence. The execution of decisions and other acts, of the measures of the People's Committee and of the regulations of the higher state organs, as well as and the harmonization of the work of all the bodies of the People's Committee, under the supervision of the administration, was ensured by the President of the People's Committee.

After the creator ceased to work, the material remained in the possession of the successor until it was taken over by the Archive from the Pazin Municipality Assembly on two occasions, in 1972 and 1973. The material was then arranged provisionally, recorded and extracted from the material of related creators. Archival processing was carried out during 2016, and in September of that same year a Summary Inventory was made. The archives were arranged in accordance with the content-functional model of arrangement, according to which the individual series were formed. The Fonds consists of ten basic series: Registry Aids, General Affairs, Labour and Employment Relations, Internal Affairs, Economy, Finance, Health and Social Care, Education and Culture, Judiciary and People's Defence. Subseries and sub-subseries were set up at the lower levels of the structure, while the material was arranged chronologically at the lowest level. 


\section{RIASSUNTO \\ Inventario sommario del fondo Comitato popolare del comune-città di Pisino 1952 - 1955}

Il Comitato popolare del comune-città di Pisino fu costituito nell'aprile del 1952 in seguito alla soppressione dei comitati popolari locali di Pisino, Gallignana, Caschierga, Cattuni di Terviso e San Pietro in Selve, allora esistenti, le cui competenze vengono trasferite al Comitato popolare del comune-città di Pisino di nuova costituzione. Operò fino alla fine del mese di agosto del 1955 quando, con il nuovo riassetto amministrativo, vengono soppressi i comuni-città e passano ai comuni di nuova costituzione. Con la soppressione del Comitato popolare del comune-città di Pisino fu costituito il Comitato popolare del comune di Pisino che assume la competenza territoriale del soggetto produttore soppresso. Il Comitato popolare del distretto di Pisino fu di livello gerarchico superiore rispetto al Comitato popolare del commune-città di Pisino.

Il Comitato popolare del comune-città aveva il compito di effettuare attività esecutive relative allo sviluppo economico, comunale, sociale e culturale del comune-città. Il Comitato popolare del comune-città istituiva le commissioni fisse e periodiche incaricate di studiare in modo accurato le singole questioni e di preparare le conclusioni ed effettuare questionari del consiglio. I consigli venivano istituiti al fine di attuare le leggi e le normative del Consiglio popolare e degli organi governativi superiori nonché per effettuare lavori amministrativi. Per preparare e attuare attività di sua competenza, il Comitato popolare del comune-città ebbe la propria amministrazione con a capo un segretario. Il presidente del Comitato popolare era incaricato di controllare l'adempimento delle decisioni e di altri atti, delle misure del Comitato popolare e delle normative degli organi governativi superiori nonché il coordinamento delle attività di tutti gli organi del Comitato popolare, insieme alla sorveglianza dell'amministrazione.

In seguito alla cessazione delle attività del produttore il materiale rimase in possesso presso il successore fino al 1972 e 1973, quando, in due occasioni, fu trasferito, dall'Assemblea del Comune di Pisino all'Archivio e fu ordinato, registrato e separato dal materiale dei produttori correlati. L'indagine archivistica fu effettuata durante il 2016 e nel settembre dello stesso anno fu creato anche l'Inventario sommario. Il materiale fu ordinato secondo il modello di ordinamento contenuto - funzione, in base al quale sono state formate delle singole serie. Il fondo comprende dieci serie principali: Strumenti per la registrazione, Affari generali, Affari e gestione del personale, Lavori interni, Economia, Finanze, Sanità e protezione sociale, Istruzione e cultura, Magistratura e Difesa popolare. Ai livelli minori della struttura sono state formate delle sottoserie e sottosottoserie, e, al livello minimo, il materiale è stato ordinato in modo cronologico. 